\title{
WEBINAR SEBAGAI MEDIA SOSIALISASI PENGETAHUAN COVID19 ANAK DAN DAMPAK PSIKOLOGIS PEMBELAJARAN DARING PADA ANAK
}

\author{
Faizah Sugiarto ${ }^{1}$, Addia Salsabila $^{2}$, Shahnaz Azzahra ${ }^{3}$, Reny l'tishom ${ }^{4^{*}}$ \\ ${ }^{1-4}$ Universitas Airlangga
}

Email Korespondensi: ritihsom@fk.unair.ac.id

\begin{abstract}
ABSTRAK
COVID-19 cukup memberikan masalah serius pada kesehatan anak dan juga berdampak pada psikologis akibat pembelajaran daring yang dilakukan sehingga pengetahuan orang tua, orang dewasa, dan ataupun anak-anak tersebut dalam mengatasi hal tersebut penting. Upaya pencerdasan tersebut salah satunya bisa melalui webinar yang pada masa pandemi ini sangat banyak diadakan. Kegiatan ini merupakan upaya pengabdian masyrakat sekaligus penelitian untuk menilai metode promosi kesehatan melalui webinar terkait upaya peningkatan pengetahuan masyarakat tentang COVID19 anak dan dampak psikologis yang dialami anak dari metode daring. Webinar ini dilakukan pada Juli 2020 dengan melibatkan 371 koresponden masyarakat Indonesia. Kegiatan ini sekaligus meneliti secara potong-lintang menggunakan metode one group pretest-postetst design untuk membandingkan nilai pretest-postest dengan metode intervensi untuk menambah pengetahuannya melalui pelaksanaan webinar. Hasil secara keseluruhan menunjukkan bahwa webinar cukup signifikan sebagai intervensi untuk meningkatkan pengetahuan sebanyak 43\% responen ( $p$-value<0.05). Webinar merupakan salah satu yang cukup efektif dalam meningkatkan pengetahuan peserta.
\end{abstract}

Kata Kunci: Webinar, COVID19, Anak, Pembelajaran Daring, Psikologi

\begin{abstract}
COVID-19 has caused a serious issue for the children's health and impacted psychologically due to online learning. Thus, the knowledge and awareness in overcoming this issue is important among parents, adults, and children. One of these intellectual efforts can be conducted through webinars, which are often held during the pandemic. This study aims to analyze the effectiveness of the webinar's method in increasing the public's knowledge and awareness about the intricacies of COVID-19 among children as well as the psychological impact experienced by those children resulting from online learning methods. This webinar was held in July 2020 involving 371 Indonesian correspondents. This activity also conducted cross-sectional research using the one group pretestposttest design method to compare the pretest-posttest scores with the intervention method to increase their knowledge through the implementation of webinars. The overall results showed the significancy of webinars as an intervention for increasing the knowledge of the participants. Webinars are one of the effective methods in increasing the participants' knowledge.
\end{abstract}

Keywords: Webinar, COVID19, Children, Online learning, Psychology 


\section{PENDAHULUAN}

Pandemi COVID19 sangat berpengaruh signifikan pada aspek kehidupan anak-anak. Anak-anak merupakan populasi yang juga berisiko selama terjadi kegawatan nasional seperti pandemi ini. (Kusumaningrum et al., 2021) Anak merupakan korban yang tidak tampak. Padahal dampak pandemi ini sangat mempengaruhi kesehatan, kesejahteraan, perkembangan, dan masa depan anak secara nyata.(UNICEF, 2021). Peningkatan kasus yang terjadi di Indonesia membuat pemerintah harus membuat kebijakan baru. Intervensi yang baru-baru ini dilakukan kembali oleh pemerintah Indonesia untuk mengatasi kasus yang terus meningkat pada beberapa waktu akhir adalah dengan menerapkan Pemberlakuan Pembatasan Kegiatan Masyarakat (PPKM). Kegiatan program PPKM ini mencakup penutupan sekolah, tempat ibadah, dan ruang umum publik lainnya serta pembatasan aktivitas pada beberapa sektor lainnya. (Menteri Dalam Negeri Republik Indonesia, 2021) Olah karena itu, selain dampak kesehatan secara fisik dapat dialami oleh anak-anak, anak-anak juga rentan terkena dampak kesehatan mental. Trauma psikologis yang mereka alami bisa dikarenakan berbagai sebab misalnya pisah dengan orang tua atau kematian orang tua, perubahan kegiatan sehari-hari, ketidakmampuan untuk mengakses pendidikan yang layak.(Kusumaningrum et al., 2021).

Peningkatan pengetahuan masyarakat tentang COVID19 dan hal-hal yang terkait dengannya merupakah hal yang penting. Peningkatan pengetahuan merupakan salah satu upaya yang bisa dilakukan untuk meningkatkan perilaku partisipatif untuk menghadapi pandemic COVID19. Pengetahuan tentang coronavirus pada anak juga sangat penting untuk menilai dampak pandemic secara global termasuk menentukan upaya penanganan dan pencegahan penyakitnya.(Sandoiu, 2020) Begitu juga peningkatan pemahaman masyakat tentang seluk-beluk pembelajaran daring selama pandemic pada anak sekolah juga penting diketahui oleh masyarakat terutama orang tua, guru, dan anak agar berbagai dampak buruk yang muncul melalui pembelajaran daring dapat dicegah dan diatasi sehingga pembelajaran bisa menjadi lebih efektif dan efisien dengan tetap memperhatikan aspek pencegahan penyebaran virus corona.

Webinar dapat menjadi media baru dengan keuntungannya yang banyak yaitu menghemat biaya, waktu, dan tenaga dan dapat diikuti oleh banyak orang dalam waktu bersamaan serta sangat memungkinan untuk penyimpanan informasi berbasis web. Oleh karena itu, webinar bisa menjadi salah satu pilihan untuk media pembelajaran untuk meningkatkan pengetahuan dan kompetensi.(Silvianita \& Yulianto, 2020) Pengkajian tentang manfaat webinar sebagai media untuk meningkatkan pengetahuan suatu kelompok di Indonesia pernah dilakukan oleh beberapa peneliti sebelumnya. E. M. Wardani et al., (2021) mengadakan promosi kesehatan untuk pencegahan transmisi COVID19 melalui webinar series.

Melalui berbagai pertimbangan tersebut, peneliti tertarik untuk menilai bagaimana penggunaan webinar yang sekali waktu dengan judul terhadap peningkatan pengetahuan masyarakat Indonesia tentang COVID19 pada anak dan kesadaran dampak psikologis pembelajaran daring pada anak. 


\section{MASALAH}

Permasalahan yang diangkat pada penelitian ini karena kasus COVID19 yang meningkat menimbulkan berbagai konsekuensi yang juga dialami oleh anak. Dampak yang terjadi dapat berupa dampak pada kesehatan anak secara langsung yaitu dengan terinfeksi oleh virus coronavirus ataupun dampak pada psikologisnya akibat pembalajaran jarak jauh yang diterapkan oleh pemerintah. Hal ini harus menjadi perhatian bersama. Salah satu upaya yang bisa dilakukan adalah dengan membagikan informasi pentingnya mengenali COVID19 pada anak dan beberapa perilaku pengasuhan yang tepat agak dampak COVID19 pada anak tidak semakin besar. Kegiatan promosi kesehatan yang bisa dilakukan adalah dengan mengadakan webinar dalam rangka meningkatkan pengetahuan dan kedaran masyarakat tentang pentingnya hal ini. Kegiatan ni dilakukan secara daring sehingga tidak ada peta kegiatan yang dapat ditampilan.

\section{METODE}

Kegiatan pengabdian masyarakat ini dilakukan dengan mengadakan webinar yang berjudul PRECISION: Prevent COVID19 and Increase State of Well Being in Children. Webinar ini turut mengundang dua pemateri ahli yaitu dokter spesialis anak konsultan respiratori dan psikiater pendidikan dan tumbuh kembang anak. Intervensi ini hanya dilakukan dalam sekali waktu yaitu dengan satu kali pelaksanaan webinar saja. Materi yang dibawakan untuk meningkatkan pengetahuan masyarakat adalah tentang bahaya COVID19 pada anak, upaya-upaya pencegahan dan penanganan COVID19 pada anak, dampak psikologis pembelajaran daring akibat pandemi pada anak, dan upaya-upaya yang perlu diperhatikan agar tumbuh kembang anak selama pembelajaran daring tetap optimal. Kegiatan ini diawali dengan membentuk panitia pelaksana, membuat proposal kegiatan, menghubungi narasumber, melakukan publikasi acara, membuat grup whatsapp untuk koordinasi dengan peserta, hingga menyenggalarkan webinar sekali waktu.

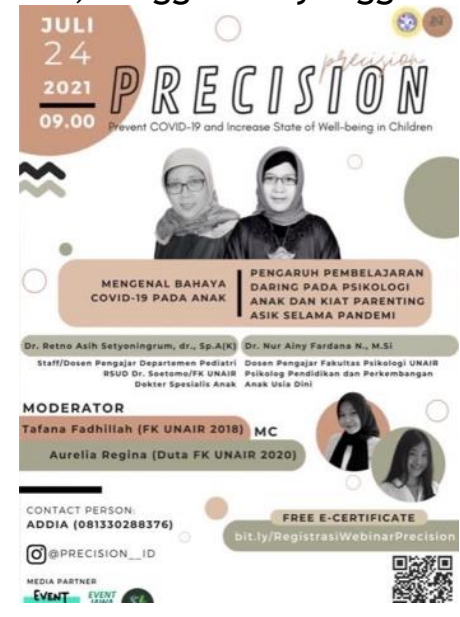

Gambar 1. Poster publikasi webinar 
4. HASIL

Tema yang diangkat pada webinar ini adalah COVID19 pada anak dan Dampak pembelajaran daring terhadap psikologis anak. Webinar ini mengundang dua pemberi materi yang sebelumnya sudah ditentukan dan sesuai menurut tema. Materi yang dibawakan untuk meningkatkan pengetahuan masyarakat adalah tentang bahaya COVID19 pada anak, upayaupaya pencegahan dan penanganan COVID19 pada anak, dampak psikologis pembelajaran daring akibat pandemic pada anak, dan upaya-upaya yang perlu diperhatikan agar tumbuh kembang anak selama pembelajaran daring tetap optimal. Kami menyewa platform zoom sebagai media pelaksanaan webinar dan menjalin media patner untuk memperluas informasi tentang webinar agar dijangkau masyarakat lebih luas lagi. Kegiatan ini dilakukan pada tanggal 24 Juli 2021 secara daring melalui aplikasi digital zoom meeting. Webinar berlangsung selama 3 jam dengan 2 narasumber pukul 09.00- 12.00 .

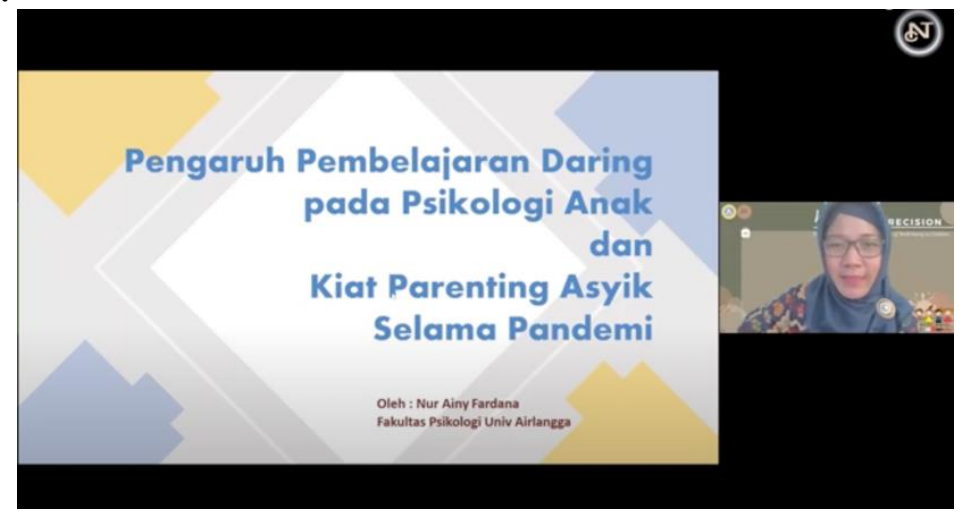

Gambar 2. Penyampaian materi dampak psikologis pembelajaran daring terhadap anak dan tips parenting selama pandemi

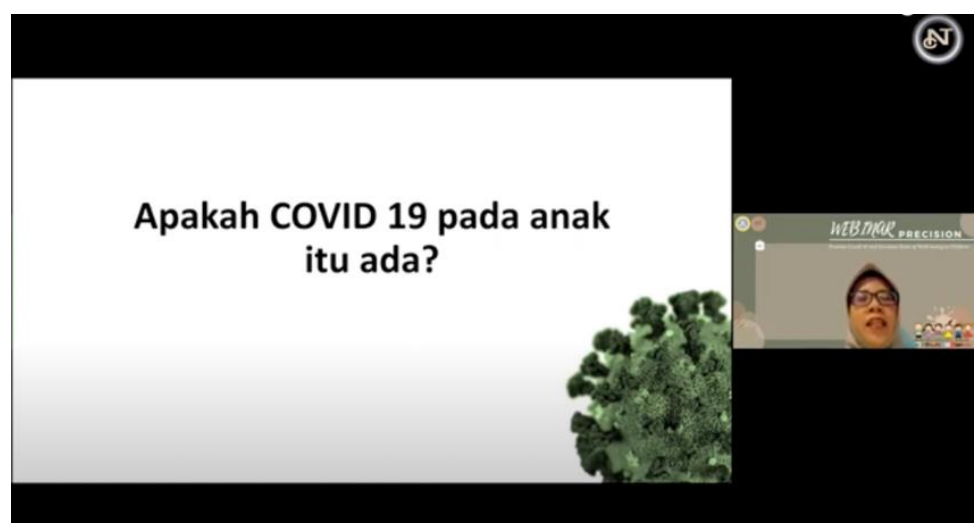

Gambar 3. Penyampaian materi COVID19 pada anak

Kami juga mengadakan tes untuk menilai bagaimana pengaruh webinar ini terhadap kemampuan masyarakat sebelum dan sesudah diberikan materi. Pada saat mulai peserta akan diberikan absen dan pretest terlebih dahulu dan setelah webinar berkahir peserta diberi posttest untuk bahan evaluasi. Sebagai bahan evaluasi secara komprehensif maka kami menggunakan one group pretest-posttest design. Instrumen penelitian yang digunakan adalah kuesioner yang dibagikan secara online menggunakan google form melalui fitur chat di zoom meeting saat sebelum dan setelah webinar untuk penyampaian materi berlangsung, selanjutnya dari hasil pretest dan posttest 
yang terkumpul akan kami lakukan analisis secara statistic dengan menginput hasil pretes dan postes di software SPSS menggunakan uji regresi komparasi dengan tingkat signifikansi $5 \%$ dan interval kepercayaan $95 \%$ pada setiap aspek yang dinilai.

Sebanyak 371 peserta berasal dari latarbelakang yang beragam. Penelitian ini menggunakan beberapa variabel untuk mengidentifkasi latarbelakang tersebut yaitu jenis kelamin, usia, pekerjaan, dan asal daerah. Tabel 1 berikut ini merupakan data karakteristik peserta yang bersedia mengikuti penelitian ini

Tabel 1. Karakteristik Responden

\begin{tabular}{|c|c|c|}
\hline Variabel & $\begin{array}{l}\text { Jumlah } \\
(\mathrm{N}=371)\end{array}$ & Presentase \\
\hline \multicolumn{3}{|l|}{ Jenis Kelamin } \\
\hline Laki-laki & 68 & $18 \%$ \\
\hline Perempuan & 303 & $82 \%$ \\
\hline \multicolumn{3}{|l|}{ Usia } \\
\hline$<20$ & 193 & $52 \%$ \\
\hline $20-29$ & 144 & $39 \%$ \\
\hline $30-39$ & 28 & $8 \%$ \\
\hline$>40$ & 6 & $1 \%$ \\
\hline \multicolumn{3}{|l|}{ Pekerjaan } \\
\hline Dosen/Guru & 13 & $4 \%$ \\
\hline Ibu rumah tangga & 3 & $1 \%$ \\
\hline Lainnya & 13 & $4 \%$ \\
\hline Mahasiswa & 242 & $65 \%$ \\
\hline Pelajar & 75 & $20 \%$ \\
\hline Tenaga kesehatan & 25 & $7 \%$ \\
\hline \multicolumn{3}{|l|}{ Daerah Asal } \\
\hline Jawa Timur & $35 \%$ & \\
\hline Jawa Tengah & $14 \%$ & \\
\hline Jawa Barat & $14 \%$ & \\
\hline Sulawesi & $9 \%$ & \\
\hline DKI Jakarta & $5 \%$ & \\
\hline Lainnya & $23 \%$ & \\
\hline
\end{tabular}


Berdasarkan tabel tersebut, responded didominasi oleh perempuan. Usia responden tebanyak pada rentang usia kurang dari 20 tahun. Kebanyakan responden juga merupakan seorang mahasiswa dibandingkan jenis pekerjaan lainnya. Selain itu juga, terbanyak berasal dari Jawa Timur.

Pada analisis pengaruh webinar, terdapat 5 kategori indikator pengetahuan yang ditanyakan kepada peserta yaitu tentang COVID19 pada anak, upaya pencegahan dan penanganan COVID19 pada anak, dampak pembelajaran daring pada anak, parenting selama mendampingi pembelajaran daring, dan aspek psikologis pembelajaran daring. Untuk mengetahui perbedaan, antara pretest dan posttest masing-masing akan dilakukan 2 tahap pengujian. Yaitu uji normalitas dan uji komparasi. Pada uji normalitas data. Nilai Sig. Pretest untuk masing-masing indicator sebesar 0,000 dan posttest sebesar 0,000. Sehingga analasis dilanjut dengan menggunakan uji Wilcoxon. Dan hasilnya ditampillkan dalam tabel 2 berikut ini.

Tabel 2. Hasil Analisa Webinar Secara Umum dan Per-Indikator Pengetahuan

\begin{tabular}{|c|c|c|c|c|c|}
\hline \multirow[b]{2}{*}{ Indikator } & \multicolumn{2}{|c|}{ Wilcoxon Test } & \multicolumn{3}{|c|}{ Tabel Deskriptif (\%) } \\
\hline & Z & $\begin{array}{l}\text { P } \\
\text { Value }^{a}\end{array}$ & $\begin{array}{l}\text { Negativ } \\
\text { e Value }^{b}\end{array}$ & $\begin{array}{l}\text { Positif } \\
\text { Value }^{c}\end{array}$ & Ties $^{d}$ \\
\hline Webinar secara umum & -5.119 & .000 & $90(24 \%)$ & $159(43 \%)$ & $122(33 \%)$ \\
\hline COVID-19 pada anak & -4.406 & .000 & $38(10 \%)$ & $95(26 \%)$ & $238(64 \%)$ \\
\hline $\begin{array}{l}\text { Pencegahan dan } \\
\text { penanganan COVID-19 anak }\end{array}$ & -2.198 & .028 & 49 (13\%) & 76 (20\%) & $246(66 \%)$ \\
\hline $\begin{array}{l}\text { Dampak pembelajaran } \\
\text { daring pada anak }\end{array}$ & -1.231 & .218 & $38(10 \%)$ & $47(26 \%)$ & $286(77 \%)$ \\
\hline $\begin{array}{l}\text { Parenting selama } \\
\text { pembelajaran daring }\end{array}$ & -493 & .622 & $20(13 \%)$ & $17(20 \%)$ & $334(90 \%)$ \\
\hline $\begin{array}{l}\text { Aspek psikologis } \\
\text { pembelajaran daring }\end{array}$ & -3.121 & .022 & $49(10 \%)$ & $82(26 \%)$ & $240(65 \%)$ \\
\hline
\end{tabular}
a. Based on negative ranks
b. Post Skor < Pre Skor
c. Post Skor > Pre Skor
d. Post Skor $=$ Pre Skor

Hasil Uji Wilcoxon pada webinar secara umum dan per-indikator penilaian menunjukkan hal yang variatif mulai dari $p$-value 0.000 - $p$-value 0.62 . Hasil tersebut menentukan bagaimana pengaruh webinar sekali waktu yang diadakan terhadap peningkatan pengetahuan masyarakat secara umum dan pada indikator pengetahuan tertentu. P-value>0.005 ditunjukan pada pengatahuan terhadap dampak pembelajaran daring pada anak dan upaya parenting selama menemani pembelajaran daring. Sedangkan kolom deskriptif menunjukkan lebih detail responden yang mengalami kenaikan, penurunan, atau tidak ada perbedaan antara nilai dari pretest dan posttest.

Secara umum, pengaruh penggunaan webinar sekali waktu menunjukkan hasil positif yang signifikan terhadap peningkatan pengatahuan masyarakat tentang COVID19 pada anak dan parenting selama masa pembelajaran daring. Peserta yang memiliki peningkatan nilai post-test 
dibanding pre-test juga paling banyak diantara indikator analisa yang lainnya. Penelitian ini sesuai dengan hasil studi metaanalisis menunjukkan bahwa webinar efektif untuk meningkatkan pencapaian pelajar. Efek webinar terhadap pertest dan postets juga menunjukkan dampak positif yang besar. Hasil yang positif juga ditunjukan dari perbandingkan efektifitas webinar daripada lingkungkan pembelajaran lain. Namun perlu diperhatikan juga jenis webinar yang diberikan diantaranya yaitu durasi, metode pemberian instruksi, teknologi yang dipakai, single atau berulang (Gegenfurtner \& Ebner, 2019). Sedangkan, pada penelitian tentang webinar series pernah dilakukan oleh Wardani et al. (2021) dengan tema yang dibawakan adalah promosi kesehatan pencegahan penularan COVID19 yang melibatkan masyarakat umum tersebut juga menunjukkan hasil yang baik yaitu ada peningkatan hasil postest dibandingkan dengan pretest. Sehingga pengetahuan masyarakat pasca pemberian webinar series meningkat. Oleh karena itu, penggunaan webinar, baik dilakukan secara sekali waktu ataupun beberapa waktu, masih bisa digunakan sebagai pilihan efektif untuk media penyampaian informasi kepada masyarakat.

Pada aspek indikator pengetahuan masyarakat tentang COVID-19 pada anak juga menunjukkan hasil yang signifikan. Secara rinci, peserta memiliki skor antara post-test dan pre-test yang tetap. Hal tersebut menunjukkan bahwa ada pengetahuan peserta tentang COVID19 pada anak ternyata sudah dapat dipahami dengan baik oleh masyarakat. Penelitian ini sejalan dengan penelitian yang dilakukan oleh Abuhammad, (2021) yaitu terkait pemahaman orang tua atau usia dewasa yang menunjukkan bahwa mereka memiliki pemahaman yang baik tentang gejala klinis, cara penularan dan tindakan perlindungan terhadap COVID19. Hampir $90 \%$ orang tua memiliki sikap yang tepat untuk menemani anaknya di keramaian karena umumnya, penularan virus COVID-19 lebih rentan terhadap virus di keramaian. Pengetahuan tentang COVID19 pada anak penting dipahami oleh masyarakat dewasa. Karena anak juga salah satu populasi yang turut menyumbang angka penungkatan kasus di COVID19 di Indonesia.

Sedangkan, indikator untuk pengetahuan tentang pencegahan dan penanganan COVID19 yang terjadi pada anak-anak juga sudah menunjukkan hal baik yang ditunjukkan melalui $p$-value yang signifikan setelah membandingkan postest dan pretest yang menilai indikator tersebut. Sebanyak $20 \%$ peserta webinar mendapatkan skor pretest lebih tinggi daripada postest dan $66 \%$ peserta dengan hasil yang sama antara nilai pretest dan postestnya. Pengetahuan dan sikap terhadap penyakit memainkan peran inti dalam menentukan kesiapan masyarakat untuk menerima tindakan perubahan perilaku sebagai tindakan untuk mencegah dan mengobati penyakit. Sebuah studi yang dilakukan oleh Miller et al., (2021) menemukan pengetahuan, harapan penyakit, dan kepatuhan secara signifikan terkait satu sama lain dan mereka yang memiliki harapan penyakit yang kuat dan pengetahuan yang rendah secara tidak proporsional berisiko gagal untuk mematuhi perilaku yang direkomendasikan terhadap suatu penyakit.

Sedangkan, webinar dinilai tidak berpengaruh signifikan terhadap peningkatan pengetahuan dampak pembelajaran daring pada anak. Sebanyak $77 \%$ responden tidak mengalami kenaikan dan penurunan pada nilai postestnya. Hal ini memungkinan terjadi karena pelajar tidak hanya sudah mengetahui hal tersebut namun juga sudah merasakan dampak tersebut mengingat bahwa kebanyakan responden pada penelitian ini adalah pelajar ataupun mahasiswa. 
Analisis peningkatan pengetahuan parenting dalam menemani anak belajar daring selema pandemi juga menunjukkan hasil yang tidak signifikan. Hal ini berarti bahwa pengaruh webinar tidak mengubah pengetahuan peserta webinar tentang parenting pada saat anak menjalani pembelajaran daring. Sebesar $90 \%$ peserta webinar memiliki nilai postett yang sama dengan pretestnya. Hal ini bisa saja terjadi karena pengetahuan tersebut memang sudah diketahui dengan baik oleh seluruh masyarakat. Berdasarkan hasil penelitian Narayani et al., (2021) terdapat hubungan yang signifikan antara pola asuh orang tua dan disiplin belajar secara daring terhadap hasil belajar di masa pandemi COVID-19. Masyarakat mungkin sudah sangat paham tentang pola asuh yang baik selama pandemi, namun pelaksanannya saja yang kemungkinan masih belum maksimal. Salah satu kendala yang mungkin dialami orang tua adalah keterbatasan penguasaan teknologi sehingga orang tua tidak bisa menemani anak secara penuh. (Sakti, 2021)

Pada penelitian ini juga didapatkan bahwa pengetahuan masyarakat tentang dampak psikologis pembelajaran daring pada anak melalui webinar ini dapat meningkat. Melalui penelitian ini didapatkan pula bahwa hanya sebesar $10 \%$ peserta webinar saja yang mengalami penurunan nilai postest. Sedangkan sisanya adalah mengalami kenaikan hasil atau hasilnya tetap. Pengetahun ini penting untuk dipahami oleh masyarakat agar masyarakat juga lebih sadar bahwa pembelajaran daring selain berdampak pada perkembangan fisik anak, juga berdampak pada mental secara psikis. Pembelajaran online bahkan dapat membuat siswa kurang termotivasi karena banyaknya tugas yang diberikan secara online. Gangguan psikis akan sangat mempengaruhi produktivitas sehari-hari. Remaja yang mengalami stress dan kecemasan akan susah berkonsentrasi(High Focus Centers, 2020).

\section{KESIMPULAN}

Webinar cukup efektif untuk meningkatkan pengetahuan masyarakat meskipun pelaksanaan webinar hanya dalam sekali waktu. Namun penelitian ini masih memiliki beberapa keterbatasan yang perlu diperhatikan juga. Pertama adalah sampel penelitian ini meskipun sasarannya masyarakat Indonesia secara umum tetapi belum bisa menyimpulkan secara keseluruhan dari Indonesia. Karakteristik responden yang mengikutipun tidak tersebar merata keberbagai latarbelakang yang sangat beragam di Indonesia. Pelaksanaan postets juga dilakukan segera setelah intervensi webinar diberikan. Sehingga pengukuran tingkat pengetahuannya masih baru diterima dengan baik. Selain itu juga pada penelitian ini tidak mengadakan penilaian tentang kualitas teknologi media webinar yang digunakan dan metode pemberian materi yang disampaikan oleh narasumber. Sehingga pada penelitian selanjutnya perlu adanya penelitian lanjutan dengan sebaran responden yang lebih beragam latar belakangnya untuk lebih menggambarkan masyarakat Indonesia. Perlu juga untuk mempertimbangan penilaian dari tiap tiap aspek mekanis yang mendetail pada pelaksanann webinarnya selain isi materi yang dibawakan 


\section{DAFTAR PUSTAKA}

Abuhammad, S. (2021). Parents' knowledge and attitude towards COVID-19 in children: A Jordanian Study. International Journal of Clinical Practice, 75(2), e13671. https://doi.org/10.1111/IJCP.13671

Gegenfurtner, A., \& Ebner, C. (2019). Webinars in higher education and professional training: A meta-analysis and systematic review of randomized controlled trials. Educational Research Review, 28(October), 100293. https://doi.org/10.1016/j.edurev.2019.100293

High Focus Centers. (2020). Online Learning \& Teen Mental Health | High Focus Centers. High Focus Center. https://highfocuscenters.pyramidhealthcarepa.com/the-effects-ofonline-learning-on-a-teens-mental-health/

Kusumaningrum, S., Siagian, C., \& Beazley, H. (2021). Children during the COVID-19 pandemic: children and young people's vulnerability and wellbeing in Indonesia. https: / /doi.org/10.1080/14733285.2021.1900544

Menteri Dalam Negeri Republik Indonesia. (2021). Instruksi Menteri dalam Negeri No 15 Tahun 2021 tentang Pemberlakuan Pembatasan Kegiatan Masyarakat Darurat Corona Virus Disease 19 di Wilayah Jawa dan Bali.

Miller, L. M. S., Gee, P. M., \& Katz, R. A. (2021). The Importance of Understanding COVID-19: The Role of Knowledge in Promoting Adherence to Protective Behaviors. Frontiers in Public Health, 0, 303. https://doi.org/10.3389/FPUBH.2021.581497

Narayani, K. D., Jayanta, I. N. L., \& Mahadewi, L. P. P. (2021). POLA ASUH ORANG TUA DAN DISIPLIN BELAJAR DARING TERHADAP HASIL BELAJAR DI MASA NEW NORMAL. Jurnal Pedagogi Dan Pembelajaran, 4(2). https: / /doi.org/10.23887/JP2.V4I2.37184

Sakti, S. A. (2021). Persepsi Orang Tua Siswa terhadap Pembelajaran Daring pada Masa Pandemi Covid 19 di Yogyakarta. Jurnal Obsesi : Jurnal Pendidikan Anak Usia Dini, 6(1), 71-79. https://doi.org/10.31004/OBSESI.V6I1.804

Sandoiu, A. (2020). COVID-19 and kids: Why understanding the impact on children is crucial. Medical News Today. https: / /www.medicalnewstoday.com/articles/covid-19-whyunderstanding-the-impact-on-children-is-crucial

Silvianita, S., \& Yulianto, E. (2020). Webinar Sebagai Kegiatan Peningkatan Kompetensi Widyaiswara Pada Masa Pandemi Covid-19. Paedagoria: Jurnal Kajian, Penelitian, Dan Pengembangan Kependidikan, 11(2), 113119.

UNICEF. (2021). COVID-19 dan Anak-Anak di Indonesia. https: / /www.unicef.org/press-releases/un-launches-global-

Wardani, E. M., Bistara, D. N., \& Septianingrum, Y. (2021). Promosi Kesehatan Pencegahan Penularan Infeksi Covid-19 pada Masyarakat Melalui Webinar Series. Dedication: Jurnal Pengabdian Masyarakat, $5(1)$,

71-76. https://doi.org/https://doi.org/10.31537/dedication.v5i1.441 